Manuscript ID

DOI
ZUMJ-1909-1496

10.21608/zumj.2019.16662.1496

ORIGINAL ARTICLE

\title{
Assessment of Urinary Kidney Injury Molecule-1 in Children with Iron Deficiency
} Anemia

\author{
Mohammed Mohammed Abd Elsalam ${ }^{1}$, Naglaa Ali Khalifa ${ }^{2}$, Shaaban Abd Elkader \\ Elsayed ${ }^{1}$ \\ Affiliation: \\ 1: Zagazig university, Faculty of Medicine, Department of Pediatrics. \\ 2: Zagazig university, Faculty of Medicine, Department of Clinical Pathology.
}

Corresponding author:

Mohammed Mohammed Abd Elsalam mohammedabdelsalam732@yahoo.com

$\begin{array}{ll}\text { Submit Date } & 2019-09-28 \\ \text { Revise Date } & 2019-10-21 \\ \text { Accept Date } & 2019-10-27\end{array}$

\section{ABSTRACT}

Background: Iron deficiency anemia (IDA) is a common type of anemia during childhood that can cause tissue hypoxia which plays a major role in acute kidney injury (AKI).

Aim of the study: Assessment of urinary kidney injury molecule-1 in children with iron deficiency anemia for early detection of kidney injury.

Methods: This case control study was done at pediatric departmet of Zagazig uiversity hospitals where 23 children with IDA , 23 matched healthy controls were recruited, we assessed complete blood count (CBC), serum iron, total iron binding capacity, ferritin, serum levels of creatinine $(\mathrm{Cr})$, urea , sreum electrolytes sodium $(\mathrm{Na})$, potassium $(\mathrm{K})$, calcium $(\mathrm{Ca})$, blood glucose levels, creactive protien (CRP). Urinary KIM-1 levels were measured and divided by urine creatinine .

Results: Our study showed no statistically significant differences in biochemical characteristics, serum creatinine and urea of the studied children of both case and control groups $(\mathrm{P}>0.05)$. Children with IDA had statistically significantly higher $\mathrm{KIM}-1 / \mathrm{Cr}$ ratio than control group $(\mathrm{P}<0.001)$. Negative correlations between hemoglobin, red blood cells, hematocrit levels of the studied children and urinary KIM-1/creatinine levels $(\mathrm{P} \leq 0.001)$.

Conclusion: Higher urinary KIM-1 levels in children with IDA suggest possible subclinical kidney injury despite normal levels of serum creatinine and urea.

Keywords: Anemia, kidney, injury, iron, KIM-1, creatinine.

\section{INTRODUCTION}

The World Health Organization (WHO) notified that Anemia is present in about 1.62 billion people, half of all of them caused by Iron deficiency anemia [1]. It has been declared that 273000 individuals die due to IDA yearly ${ }^{[2]}$.

Iron is transported in the blood by a carrier protein called transferrin and found in hemoglobin at the highest concentration.
Individuals with iron deficiency anemia have failure in hemoglobin production leading to impaired tissue oxygenation and hypoxia causing early kidney injury ${ }^{[3]}$.

Serum creatinine and blood urea have many disadvantages as they are affected by age, sex, muscle mass, hydration state, and drugs, also delayed till loss of about half of kidney function ${ }^{[4]}$. Therefore, we need new markers for early prediction of kidney injury. 
Kidney injury molecule-1 (KIM-1) is a cell membrane glycoprotein type I which rises from the affected part of the proximal tubules whenever any toxin or pathological state result in epithelial adaption and loss of function which considered as an early epithelial cell response to injury ${ }^{[5]}$.Therefor, KIM-1 has advantages in prediction of kidney injury ${ }^{[6]}$.

The aim of this work is assessment of urinary kidney injury molecule- 1 in children with iron deficiency anemia for early detection of kidney injury.

\section{SUBJECTS AND METHODS}

This case control study was carried out at Pediatrics department of Zagazig university hospitals on 46 children, 23 with IDA and 23 healthy controls who presented to outpatient clinics for routine visits from August 2017 to March 2018.

\section{Inclusion criteria:}

Cases: From Pediatric department of zagazig university hospitals who presented to outpatient clinics for routine visits and diagnosed with IDA, the cause of IDA was nutritional.

Healthy control: Age and sex matched healthy children who presented to outpatient clinics for routine visits without anemia, diseases affecting kidney or history of long term drug use.

\section{Exclusion criteria:}

Patients taking any drug that potentially affects kidney function, such as non-steroidal antiinflammatory drugs, angiotensin-converting enzyme inhibitors, or diuretics, Children with liver, kidney, heart, lung diseases also children with diabetes, rheumatic disease, urinary tract infection, sepsis, hypoxia and Thalassemia patients.

4-Patients or relatives who refuse to participate in the study.

\section{Methods:}

All cases were studied by Full history, Clinically and Laboratory investigations which included $\mathrm{CBC}$, iron indices (iron, ferritin, TIBC), Liver enzymes (ALT, AST), Kidney functions (Serum creatinine, urea), random blood glucose, C-reactive protien (CRP), Serum electrolytes (Na, K, Ca), Urinary KIM-1 levels and urinary creatinine and measurement of urinary KIM-1/creatinine ratio.

We collected the urine samples by using sterile containers. Then we removed any particulates by centrifugation for 15 minutes at $1000 x g, 2-8^{\circ} \mathrm{C}$ and assayed immediately or aliquoted and stored samples at $-20^{\circ} \mathrm{C}$. Levels of KIM-1 and creatinine in urine were measured by ELISA then urinary kim-1/ urinary creatinine ratio calculated.

Written informed consent was obtained from all participants and the study was approved by the research ethical committee of Faculty of Medicine, Zagazig University. The work has been carried out in accordance with The Code of Ethics of the World Medical Association (Declaration of Helsinki) for studies involving humans.

\section{Statistical analysis of results}

Data were analyzed by Statistical Package of Social Science (SPSS), software version 24.0. Continuous data were obtained as the Mean \pm SD if normally distributed or Median (Range) if not normally distributed. Normality was checked by Shapiro test. Categorical data were presented by the count and percentage. Results were compaired using the chi-squared test, Independent-samples t-test, Mann-Whitney $\mathrm{u}$ test and Pearson's correlation. All statistical comparisons were two-tailed. Significance leves as follow $\mathrm{P}$-value $<0.05$ indicates significant, $\mathrm{P}<0.01$ indicates highly significant difference, $\mathrm{P}<0.001$ indicates very highly significant difference while, $\mathrm{P} \geq 0.05$ indicates no significant difference.

\section{RESULTS}

Both studied groups were properly matched regarding age and sex, there were no statistically significant differences in baseline characteristics and clinical data of the studied children $(\mathrm{P}>0.05)$ but the body weight of children with IDA was statistically significantly lower than normal children $(\mathrm{P}=0.038)$ table (1). Children with IDA had statistically significantly lower hemoglobin, RBCs, hematocrit, $\mathrm{MCV}$ and $\mathrm{MCH}$ levels than normal children $(\mathrm{P}<0.001)$ table $(2)$. Children with IDA 
had a significant decrease in serum iron \& ferritin levels and a significant increase in total iron binding capacity levels compared with normal children $(\mathrm{P}<0.001)$ table $(3)$. There were no statistically significant differences in liver enzymes (ALT, AST), renal functions (S.cr, BUN), electrolytes (Na, K, Ca) and random blood glucose (RBS) of the studied children (P>0.05) table (4). Children with IDA had statistically significantly higher KIM-1/Cr ratio than normal children $(\mathrm{P}<0.001)$ table $(5)$.
There were strong negative statistically significant correlations between $\mathrm{KIM}-1 / \mathrm{Cr}$ ratio and $\mathrm{CBC}$ parameters of the studied children $(\mathrm{P} \leq 0.001)$ table $(6)$. There were strong negative statistically significant correlations between $\mathrm{KIM}-1 / \mathrm{Cr}$ ratio and serum iron\& ferritin levels $(\mathrm{P}<0.001)$ and a moderate positive correlation between $\mathrm{KIM}-1 / \mathrm{Cr}$ and total iron binding capacity of the studied children $(\mathrm{P}=0.002)$ table (7).

Table 1: Baseline characteristics of the studied children

\begin{tabular}{|c|c|c|c|c|}
\hline \multirow[t]{2}{*}{ Variables } & Controls & Cases & \multirow[t]{2}{*}{ Significance test } & \multirow[t]{2}{*}{ P-value } \\
\hline & $n=23$ & $\mathrm{n}=23$ & & \\
\hline Age(months) & & & MW=204.5 & 0.19 \\
\hline Median(Range) & $24(6-60)$ & $15.6(5-54)$ & & \\
\hline Sex, n, (\%) & & & $\chi^{2}=0$ & $>0.99$ \\
\hline Females, n, (\%) & $9(39 \%)$ & $9(39 \%)$ & & \\
\hline Males, $n,(\%)$ & $14(61 \%)$ & $14(61 \%)$ & & \\
\hline Body weight (Kg) & & & $\mathrm{MW}=170$ & 0.038 \\
\hline Median(Range) & $12.5(8-21.5)$ & $9.8(5.5-17)$ & & \\
\hline
\end{tabular}

Table 2: Complete blood count and inflammatory marker of the studied children

\begin{tabular}{|c|c|c|c|c|}
\hline \multirow[t]{2}{*}{ Variables } & Controls & Cases & \multirow[t]{2}{*}{ Significance test } & \multirow[t]{2}{*}{ P-value } \\
\hline & $\mathrm{n}=23$ & $\mathrm{n}=23$ & & \\
\hline Hemoglobin (g/dL) & & & \multirow{2}{*}{$\begin{array}{l}\text { Independent } \\
\text { sample-t test }=7.8\end{array}$} & \multirow[t]{2}{*}{$<0.001$} \\
\hline Mean \pm SD & $11.7 \pm 1.0$ & $8.9 \pm 1.4$ & & \\
\hline Hematocrit (\%) & & & \multirow[t]{2}{*}{ MW=6.5 } & \multirow[t]{2}{*}{$<0.001$} \\
\hline Median(Range) & $36(31.1-56)$ & $26(20.3-35)$ & & \\
\hline RBCs $\left(\times 10^{6}\right.$ cells $\left./ \mu \mathrm{L}\right)$ & & & \multirow{2}{*}{$\begin{array}{l}\text { Independent } \\
\text { sample-t test }=11.2\end{array}$} & \multirow[t]{2}{*}{$<0.001$} \\
\hline Mean \pm SD & $4.5 \pm 0.4$ & $3.4 \pm 0.3$ & & \\
\hline MCV (fL) & & & \multirow[t]{2}{*}{$\mathrm{MW}=0$} & \multirow[t]{2}{*}{$<0.001$} \\
\hline Median(Range) & $83.1(76.9-113)$ & $63.9(50-68)$ & & \\
\hline MCH & & & \multirow[t]{2}{*}{$\mathrm{MW}=0$} & \multirow[t]{2}{*}{$<0.001$} \\
\hline Median(Range) & $26.6(24.1-35)$ & $21.6(15.1-24)$ & & \\
\hline $\begin{array}{l}\text { C-reactive protein, } \\
\mathrm{n},(\%)\end{array}$ & & & ------ & --------- \\
\hline Negative & $23(100 \%)$ & $23(100 \%)$ & & \\
\hline
\end{tabular}


Table 3: Serum iron indices of the studied children

Variables Controls Cases

Significance test P-value

\begin{tabular}{|c|c|c|c|c|}
\hline & $\mathrm{n}=23$ & $\mathrm{n}=23$ & \multirow{3}{*}{$\mathrm{MW}=0$} & \multirow{3}{*}{$<0.001$} \\
\hline \multicolumn{3}{|l|}{$\operatorname{Iron}(\mu \mathrm{g} / \mathrm{dL})$} & & \\
\hline Median(Range) & $135(66-160)$ & $32(21.2-47)$ & & \\
\hline Ferritin $(\mu \mathrm{g} / \mathrm{dL})$ & & & $\begin{array}{l}\text { Independent } \\
\text { sample-t } \\
\text { test=34.3 }\end{array}$ & $<0.001$ \\
\hline Mean \pm SD & $92.8 \pm 11.3$ & $11.3 \pm 0.9$ & & \\
\hline TIBC $(\mu \mathrm{g} / \mathrm{dL})$ & & & Independent & $<0.001$ \\
\hline Mean \pm SD & $260 \pm 25$ & $396 \pm 46$ & $\begin{array}{l}\text { sample-t } \\
\text { test }=12.5\end{array}$ & \\
\hline
\end{tabular}

MW, Mann-Whitney u test

Table 4: Biochemical characteristics (liver enzymes, kidney function test, serum electrolytes and random blood sugar) of the studied children

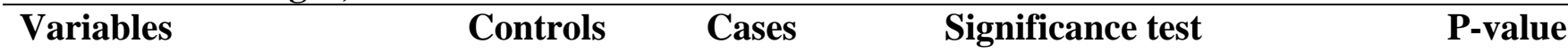

$\mathrm{n}=23 \quad \mathrm{n}=23$

\begin{tabular}{lll}
\hline ALT (IU/L) & MW=274.5 & 0.83 \\
\cline { 1 - 2 } Median(Range) & $21(11.8-32)$ & $21(10.5-38.2)$
\end{tabular}

\begin{tabular}{|c|c|c|c|c|}
\hline AST (IU/L) & & & Independent sample-t test $=1.8$ & 0.074 \\
\hline Mean \pm SD & $24.7 \pm 4.8$ & $27.9 \pm 6.9$ & & \\
\hline $\begin{array}{l}\text { Sodium } \\
(\mathrm{mg} / \mathrm{dL})\end{array}$ & & & $M W=241$ & 0.60 \\
\hline Median(Range) & 137(134-143) & 136(133-143) & & \\
\hline $\begin{array}{l}\text { Potassium } \\
\text { (mg/dL) }\end{array}$ & & & Independent sample-t test $=0.5$ & 0.62 \\
\hline Mean \pm SD & $4.17 \pm 0.49$ & $4.25 \pm 0.57$ & & \\
\hline $\begin{array}{l}\text { Calcium } \\
(\mathrm{mg} / \mathrm{dL})\end{array}$ & & & Independent sample-t test $=1.04$ & 0.30 \\
\hline Mean \pm SD & $9.6 \pm 0.8$ & $9.4 \pm 0.6$ & & \\
\hline Serum creatinine (mg/dL) & & & Independent sample-t test $=1.8$ & 0.074 \\
\hline Mean \pm SD & $0.43 \pm 0.14$ & $0.35 \pm 0.16$ & & \\
\hline BUN (mg/dL) & & & Independent sample-t test $=0.43$ & 0.67 \\
\hline Mean \pm SD & $5.9 \pm 1.5$ & $6.2 \pm 2.3$ & & \\
\hline RBS(mg/dL) & & & Independent sample-t test $=0.31$ & 0.76 \\
\hline Mean \pm SD & $118.3 \pm 23.6$ & $116.1 \pm 24.5$ & & \\
\hline
\end{tabular}


Table 5: Urinary Kidney Injury Molecule-1/urinary creatinine (KIM-1/Cr ratio) of the studied children

\begin{tabular}{lllll}
\hline Variables & Controls & Cases & $\begin{array}{l}\text { Independent } \\
\text { sample-t test }\end{array}$ & P-value \\
\cline { 2 - 3 } & $\mathrm{n}=23$ & $\mathrm{n}=23$ & $\mathrm{t}=5.3$ & $\mathbf{0 . 0 0 1}$ \\
\hline KIM-1/Cr ratio & & & &
\end{tabular}

KIM-1, human kidney injury molecule; $\mathrm{Cr}$, creatinine

Table 6: Correlations between Urinary Kidney Injury Molecule-1/urinary creatinine (KIM-1/Cr ratio) and complete blood count of the studied children

Variables

Hemoglobin (g/dl)

\begin{tabular}{|c|c|c|}
\hline \multirow[t]{2}{*}{ Hemoglobin (g/dl) } & $\mathbf{R}$ & -0.492 \\
\hline & $\mathbf{P}$ & 0.001 \\
\hline \multirow[t]{2}{*}{ Hematocrit (\%) } & $\mathbf{R}$ & -0.687 \\
\hline & $\mathbf{P}$ & $<0.0001$ \\
\hline \multirow[t]{2}{*}{ RBCs $\left(\times 10^{6}\right.$ cells $\left./ \mu \mathrm{L}\right)$} & $\mathbf{R}$ & -0.662 \\
\hline & $\mathbf{P}$ & $<0.0001$ \\
\hline \multirow[t]{2}{*}{ MCV (fL) } & $\mathbf{R}$ & -0.591 \\
\hline & $\mathbf{P}$ & $<0.0001$ \\
\hline \multirow[t]{2}{*}{ MCH(Unit) } & $\mathbf{R}$ & -0.471 \\
\hline & $\mathbf{P}$ & 0.001 \\
\hline
\end{tabular}

r:Pearson correlation coefficient, RBCs, Red blood cells; MCV; Mean corpuscular volume; MCH,Mean corpuscular hemoglobin

Table 7 : Correlations between Urinary Kidney Injury Molecule-1/urinary creatinine (KIM-1/Cr ratio) and iron indices of the studied children

Variables

KIM-1/Cr ratio

\begin{tabular}{lll}
\hline Iron $(\boldsymbol{\mu g} / \mathbf{d L})$ & $\mathbf{R}$ & -0.591 \\
\cline { 2 - 3 } & $\mathbf{P}$ & $<\mathbf{0 . 0 0 1}$ \\
\hline Ferritin $(\boldsymbol{\mu g} / \mathbf{d L})$ & $\mathbf{R}$ & -0.606 \\
\cline { 2 - 3 } & $\mathbf{P}$ & $<\mathbf{0 . 0 0 1}$ \\
\hline TIBC $(\boldsymbol{\mu g} / \mathbf{d L})$ & $\mathbf{R}$ & 0.451 \\
\cline { 2 - 3 } & $\mathbf{P}$ & $\mathbf{0 . 0 0 2}$ \\
\hline
\end{tabular}

r:Pearson correlation coefficient, TIBC, total iron binding capacity

\section{DISCUSSION}

Our study investigated the urinary KIM1levels in children suffer from IDA for early prediction of kidney injury. This case-control study was conducted on 23 children with IDA as case group compared to 23 healthy children as a control group.
As regard, anthropometric measures and clinical data of the studied children we observed that the weight of case group ranged from $5.5 \mathrm{~kg}$ to $17 \mathrm{~kg}$ and in control group ranged from $8 \mathrm{~kg}$ to $21.5 \mathrm{~kg}$ so body weight of children with IDA was statistically significantly lower than normal children. These results agreed 
with Al Ghwass et al. ${ }^{[7]}$ who studied IDA in Egyptian children and reported that stunting, wasting and underweight were associated with IDA. Also Akodu et al. ${ }^{[8]}$ studied IDA in apparently healthy pre-school children in Lagos, Nigeriaand and noticed that underweight was associated with IDA.

We observed that children with IDA had statistically significantly higher $\mathrm{KIM}-1 / \mathrm{Cr}$ ratio than normal children which indicates that iron deficiency anemia can cause kidney injury. Also Gunes et al. ${ }^{[9]}$ investigated kidney injury markers in children with IDA and concluded that IDA children had significantly higher levels of urinary $\mathrm{KIM}-1 / \mathrm{Cr}$, NGAL/Cr, L$\mathrm{FABP} / \mathrm{Cr}$, and NAG/Cr.

In our study serum creatinine, BUN, electrolytes, ALT, AST and RBS values were within normal ranges in both IDA group and control group indicating that serum creatinine is a late marker for detection of kidney injury. Also Akdeniz et al. ${ }^{[10]}$ studied contrastinduced nephropathy and reported that creatinine is a sensitive but a late marker.

In our results we observed strong negative statistically significant correlations between $\mathrm{KIM}-1 / \mathrm{Cr}$ ratio and $\mathrm{CBC}$ parameters (Hb, Hct, RBCs, MCV and $\mathrm{MCH}$ ) of the studied children indicating that kidney injury increased when anemia got worsen. This came in agreement with Daniel ${ }^{[11]}$ who investigated anemia and AKI in hospitalized patients, and found that during hospitalization, patients with AKI had lower hemoglobin levels.

Our study showed strong negative statistically significant correlations between $\mathrm{KIM}-1 / \mathrm{Cr}$ ratio and serum iron\& ferritin levels and a moderate positive correlation between total iron binding capacities of the studied children. Also El-Shimi et al. ${ }^{[12]}$ mentioned that IDA had an adverse effect on renal function and structure which could be reversed with iron therapy.

Our study have significant limitations including the small sample size and that we were not able to study the effect on weight and other anthropometric parameters after the treatment of IDA, due to the discharge of IDA patients.Also, we were not able to study the urine marker KIM-1 after the treatment of IDA. These limitations were partially resolved by comparison with the control group.It seems that further studies on a larger scale are warranted to delineate the correlation of IDA and AKI and utility of KIM-1 as a powerful predictor of kidney injury.

\section{CONCLUSION}

The study concluded that higher urinary KIM-1 levels in children with IDA suggest possible subclinical kidney injury despite normal levels of serum creatinine and urea. Follow up of children with IDA for kidney injury by using KIM-1 is recommended before and after treatment.

Conflict of interest: - No Conflict of interest

Financial disclosure: - No funding or grants REFERENCES

1. Charles CV, Summerlee AJ, Dewey CE. Anemia in Cambodia: prevalence, etiology and research needs. Asia Pac J Clin Nutr. 2012; 21(2): 171181.

2. Pasricha SR, Drakesmith $\mathrm{H}$, Black J, Hipgrave D, Biggs BA. Control of iron deficiency anemia in low- and middle-income countries. Blood 2013 121:2607-2617.

3. Nangaku M. Chronic hypoxia and tubulointerstitial injury: a final common pathway to end-stage renal failure. $\mathrm{J}$ Am Soc Nephrol. 2006 Jan; 17(1): 17-25.

4. J. Mårtensson, C-R Martling, M. Bell. Novel biomarkers of acute kidney injury and failure: clinical applicability. $\mathrm{Br} \quad \mathrm{J}$ Anaesth. 2012 Dec; 109(6): 843-850.

5. Bonventre JV. Dedifferentiation and proliferation of surviving epithelial cells in acute renal failure. $\mathbf{J}$ Am Soc Nephrol. 2003 Jun; 14 (Suppl 1): S55S61.

6. Najafi M. Serum creatinine role in predicting outcome after cardiac surgery beyond acute kidney injury. World J Cardiol. 2014 Sep 26; 6(9):1006-21.

7. Al Ghwass MM, Halawa EF, Sabry SM, Ahmed

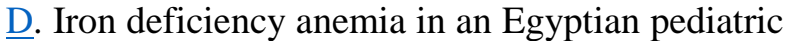
population: A cross-sectional study. Ann Afr Med. 2015 Jan-Mar; 14(1):25-31.

8. Akodu OS, Disu EA, Njokanma OF, Kehinde OA. Iron deficiency anaemia among apparently healthy 
pre-school children in Lagos, Nigeria. Afr Health Sci. 2016 Mar; 16(1):61-8.

9. Güneş A, Ece A, Aktar F, Tan İ, Söker M, Karabel $D$, et al. Urinary Kidney Injury Molecules in Children with Iron-Deficiency Anemia. Med Sci Monit. 2015 Dec 24; 21:4023-9.

10. Akdeniz D, Celik HT, Kazanci F, Yilmaz $\underline{\mathrm{H}}$, Yalcin S, Bilgic MA, et al. Is Kidney Injury Molecule 1 a Valuable Tool for the Early Diagnosis of Contrast-Induced Nephropathy? J Investig Med. 2015 Dec;63(8):930-4
11. Daniel M. Keller. Anemia Raises Risk for Acute Kidney Injury, Poorer Recovery - Medscape Nov 14, 2014.

12. El-Shimi MS, El-Farrash RA, Ismail EA, El-Safty IA, Nada AS, El-Gamel OA, et al. Renal functional and structural integrity in infants with iron deficiency anemia: relation to oxidative stress and response to iron therapy. $\underline{\text { Pediatr }}$ Nephrol. $2015 \quad$ Oct; $30(10): \overline{1835-42 .}$

How to Cite elsayed, S., Khalifa, N., abd elsalam, M. Assessment of urinary kidney injury molecule-1 in children with iron deficiency anemia. Zagazig University Medical Journal, 2021; (485-491): -. doi: 10.21608/zumj.2019.16662.1496 